\title{
Working
}

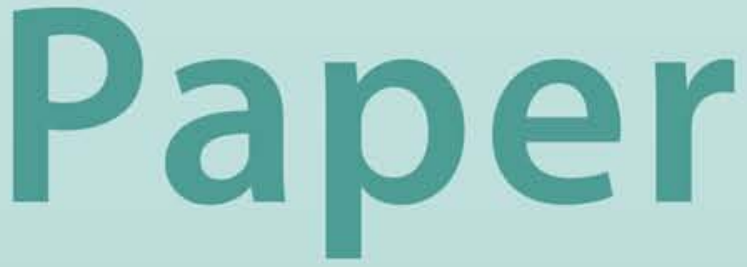




\title{
Interpreting Real Exchange Rate Movements in Transition Countries
}

\author{
Mark De Broeck and Torsten Sløk
}




\title{
IMF Working Paper
}

European I and Research Departments

\section{Interpreting Real Exchange Rate Movements in Transition Countries}

\author{
Prepared by Mark De Broeck and Torsten Sløk ${ }^{1}$
}

Authorized for distribution by Tamim Bayoumi and Juha Kähkönen

May 2001

\begin{abstract}
The views expressed in this Working Paper are those of the author(s) and do not necessarily represcnt those of the IMF or IMF policy. Working Papers describe research in progress by the author(s) and are published to clicit comments and to further debate.
\end{abstract}

Several transition countries have experienced strong real exchange rate appreciations. This paper tests the hypothesis that these appreciations reflect underlying productivity gains in the tradable sector. Using panel data over the period 1993-98, the results show clear evidence of productivity-driven exchange rate movements in the central and eastern European and Baltic countries. Transition countries, particularly the EU accession countries that have begun to catch up, can expect to experience further productivity-driven real exchange rate appreciations. Evidence from a large cross-section of non-transition countries indicates that catching up by one percent will be associated with a 0.4 percent real appreciation.

JEL Classification Numbers: F30, G14, G15, P34

Keywords: Real exchange rates, transition, Balassa-Samuelson effects

Authors' E-Mail Address: mdebroeck@imf.org and tsloek@imf.org

\footnotetext{
${ }^{1}$ We would like to thank Enrique Alberola-Ila, Tamim Bayoumi, Peter Christoffersen, Hali Edison, Juha Kähkönen, Byung-Yeon Kim, Ronald MacDonald, and participants in an internal seminar at the IMF and in a workshop at BOFIT, Helsinki, for comments and suggestions.
} 


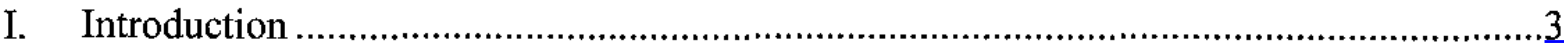

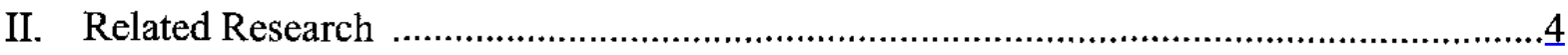

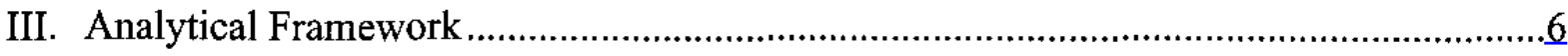

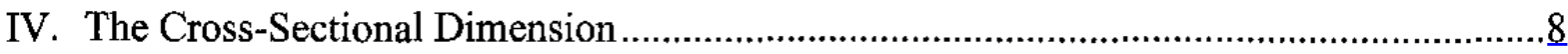

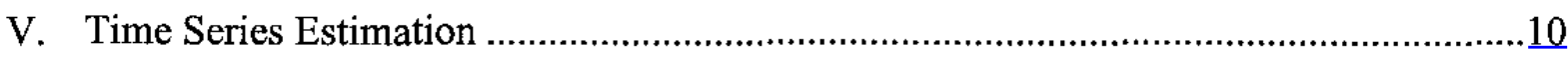

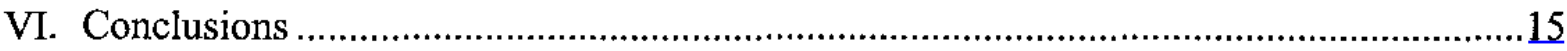

Tables

1. Explaining Movements in the Real Effective Exchange Rate, 1993-1998 …................17

2. Explaining Movements in the Real Effective Exchange Rate, 1993-1998 ….................18

3. Pooled Mean Group Estimates for Eastern Europe .....................................................19

4. Pooled Mean Group Estimates for Eastern Europe.....................................................19

5. Pooled Mean Group Estimates for other Transition Countries .....................................20

6. Pooled Mean Group Estimates for other Transition Countries ......................................20

7. Pooled Mean Group Estimates for Eastern Europe ............................................................21

8. Pooled Mean Group Estimates for Eastern Europe......................................................21

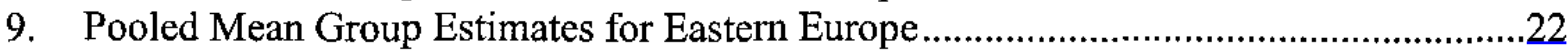

10. Pooled Mean Group Estimates for Eastern Europe …………...........................................22

Figures

1. Productivity in Industry and Real Effective Exchange Rate in Selected Countries.........23

2. Exchange Rate Gap and Income Level for the World Excluding Transition Countries ..27

3. Exchange Rate Gap and Income Level for EU Accession Countries ...............................28

4. Exchange Rate Gap and Income Level for Selected Transition Countries ......................29

Appendix

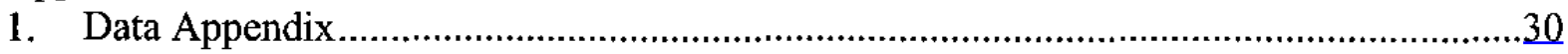

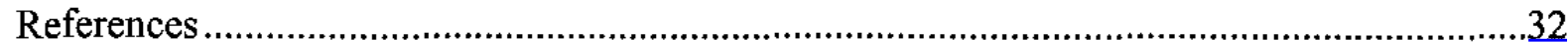




\section{INTRODUCTION}

A number of transition countries have experienced strong real exchange rate appreciations in the course of the transition process. These appreciations present a major challenge for the conduct of monetary policy since they can either reflect misalignment or be the result of an equilibrium adjustment induced by the movement toward a market-based economy. For the EU accession countries that intend to join the EMU, real exchange rate appreciation has important implications in terms of meeting the Maastricht inflation criteria. This paper addresses these issues using data for the central and eastern European transition countries, Russia and the other countries of the former Soviet Union, and Mongolia.

Real exchange rate movements can be explained by different theories, which tend to focus on either demand or supply factors (Obstfeld and Rogoff, 1996). The main supply-side based explanation is the Balassa-Samuelson "productivity hypothesis" (Balassa, 1964, and Samuelson, 1964). According to this hypothesis, productivity gains in the tradable sector (in relative terms, compared with developments in competitor countries) allow real wages to increase commensurately. Since wages are assumed to be linked between the tradable and the nontradable sector, wages and prices will also increase in the nontradable sector. This will lead to an increase in the overall price level in the economy which will in turn result in an appreciation of the real exchange rate.

This paper analyzes sectoral productivity data from the transition countries to test the BalassaSamuelson hypothesis. These countries are expected to experience substantial productivity gains as they move toward a market-based economy. Since the overall level of development in most transition countries falls short of that in the advanced economies, there is scope for general productivity convergence. Moreover, these countries have the potential for additional, transition-specific, productivity gains since, as a result of the distortions inherited from central planning, their productivity levels are below those in market economies at a comparable level of development. The transition countries therefore are good candidates to test the BalassaSamuelson hypothesis in the time-series dimension. Indeed, year-on-year productivity developments in the transition countries have generally been much more pronounced than those in the advanced and developing countries, for which time-series evidence in support of the Balassa-Samuelson hypothesis has been notoriously difficult to find. ${ }^{2}$

The transition process is still ongoing, with the various transition countries at different stages of the process. Some countries more advanced in the transition now have embarked on a path of robust growth and substantial productivity gains. Other transition countries only recently

${ }^{2}$ Applications of the Balassa-Samuelson approach to non-transition countries can be found in, for example, Alberola, Cervero, Lopez, and Ubide (1999), Bayoumi, Isard, Ito, and Symansky (1996), Calderón (2000), Canzoneri, Cumby, and Diba (1999), Chinn and Johnston (1997), De Gregorio and Wolf (1994); for a literature survey on this empirical work, see MacDonald (1998). 
have shown signs of recovery from the initial output collapse, and they have not yet been able to generate consistent productivity increases in the tradable sector. Figure 1 shows how productivity in the tradables sector has begun to pick up in the central and eastern European countries and the Baltics, but not in Russia and other countries of the former Soviet Union. The figure also shows that real exchange rates have appreciated consistently in the first group of countries. These different productivity and exchange rate patterns suggest that the BalassaSamuelson effect may be operating differently in the central and eastern European countries and the Baltics than in the other transition countries. The empirical sections in the remainder of the paper therefore present separate estimation results for these two country groupings.

\section{RELATED RESEARCH}

There is a growing literature analyzing real exchange rate movements in transition countries. ${ }^{3}$ A number of studies focus on individual transition countries, as opposed to the cross-country approach adopted in this paper. In separate studies on Poland and Romania for the period 1992-97, Maliszewska (1998) find real exchange rate developments to be in line with the predictions of a productivity-based model. Jakab and Kovács (1999) use a structural VAR model to track the sources of real exchange rate fluctuations in Hungary during 1992-98 and also establish strong support for the Balassa-Samuelson effect. Rother (2000) estimates a model incorporating the Balassa-Samuelson hypothesis for Slovenia during 1993-98 and concludes that the long-run trend in the real exchange rate appears to be fully explained by sectoral productivity differentials.

Most directly related to this paper are the cross-country studies on real exchange rates in transition by Halpern and Wyplosz (1997) and Krajnyák and Zettelmeyer (1998). ${ }^{4}$ Halpern and Wyplosz explain the typical real exchange rate path that is observed during the transition as one with an initial steep depreciation followed by a continued appreciation. They argue that the real exchange rate in the transition economies initially overshot its equilibrium path and then began to appreciate due to a combination of a return to the equilibrium path and an underlying appreciation of the equilibrium real exchange rate itself. This equilibrium appreciation in turn reflected efficiency gains stemming from structural reform.

To test this hypothesis, the authors first estimate the path of the equilibrium real exchange rate in the transition economies for the period 1991 to 1996 . Considering that the real exchange rate

\footnotetext{
${ }^{3}$ For a descriptive study of real exchange rate movements in six transition countries in the early transition years, see Liargovas (1999).

${ }^{4}$ A study by Cipriani (2000) is also close to this paper, but it focuses on aggregate inflation rather than the real exchange rate. Cipriani examines the presence of a Balassa-Samuelson effect in ten EU accession countries for the period 1995-99, and finds that a one percent increase in relative labor productivity generates, on average, a 0.7 percent increase in the relative price of nontradables.
} 
was out of equilibrium during this early transition period, they refer to a sample of pretransition data for the estimation. Their sample includes 80 countries, both market and centrally planned economies, and covers the period 1970 to 1990 , with the observations taken five years apart. Absent relevant financial and price date for the centrally planned economies, the authors use the average U.S. dollar wage to proxy the real exchange rate. The pre-transition equilibrium U.S. dollar wage (equilibrium real exchange rate) is estimated as the predicted value from a regression with a set of productivity proxies as right hand side variables. The equilibrium dollar wage during the initial transition years in turn is derived using the 1991-96 observations for these productivity proxies. The estimation results are found to be plausible and robust across specifications, and the coefficients are generally estimated quite precisely. In line with the authors' hypothesis, and with two exceptions, real exchange rates were significantly undervalued at the beginning of the transition. The gap with the equilibrium rate narrowed slowly over time, and in most cases the initial undervaluation was only partially reversed by the end of $1996 .^{5}$

The Halpern and Wyplosz (1997) estimates of equilibrium dollar wages are updated in Begg, Halpern, and Wyplosz (1999). These three authors extend the sample period to 1997, which allows them to include data from the transition countries themselves rather than from their centrally-planned predecessors. They also add some explanatory variables to the Halpern and Wyplosz regression framework. The estimation results confirm that the real appreciation observed in most transition countries during the initial transition years represented in part a correction from an initial undervaluation. However, in contrast with the Halpern and Wyplosz results, it is no longer the case that the estimated equilibrium dollar wage in all cases rose systematically throughout the period 1990 to 1997 . Also, the results are found to be less than fully satisfactory since they are to an important extent driven by unmeasured factors that are captured by dummy variables.

In line with the Halpern and Wyplosz (1997) approach, Krajnyák and Zettelmeyer (1998) also estimate equilibrium real exchange rates as a function of productivity measures, using U.S. dollar wages as a proxy for the real exchange rate. Krajnyák and Zettelmeyer, however, include a different set of transition economies in the sample and they adopt a different estimation procedure. They argue that the market economies in their sample on average were in equilibrium during the sample period 1991 to 1995 . Recognizing that the transition economies in their sample were out-of-equilibrium in that period, they also argue that a group dummy can capture adequately these out-of-equilibrium effects. Based on these two assumptions, they

\footnotetext{
${ }^{5}$ The Halpern and Wyplosz paper also analyses in more detail the forces that brought the real exchange rate back to its equilibrium path. Based on a sample of monthly data for the period 1991-96, the real exchange rate regressions are augmented with a number of variables that capture the dynamics of the real exchange rate. The additional estimation results confirm that the speed at which the real exchange rate converged to equilibrium was quite slow, as changes in the nominal exchange rate resulted in longer-lasting deviations of the real rate from equilibrium.
} 
proceed to estimate equilibrium dollar wages for both the market and transition economies within sample. Their two main results are broadly in line with those from Halpern and Wyplosz. Krajnyák and Zettelmeyer confirm that the real exchange rate was initially undervalued in the transition economies. They also find that, as real exchange rates appreciated during the initial transition years, the gap between actual and equilibrium rates declined in most of these economies, without being eliminated fully by $1995-96$, however.

This paper does not try to expand on the theoretical work on real exchange rate determination during the transition. Krajnyák and Zettelmeyer (1998) underpin their main empirical findings by a model distinguishing a tradables versus a nontradables sector. They introduce two key assumptions, namely that the tradables sector is relatively capital intensive and that capital adjustment is costly. The first assumption in steady state generates the Balassa-Samuelson property that faster productivity growth in the tradables sector is associated with a real appreciation. The second assumption allows the authors to model a sequence of short-run equilibria conditional on the level of the capital stock during the adjustment to the steady state. Capital obsolescence associated with external opening and price liberalization drives the real exchange rate below its steady state level at the beginning of the transition. During the transition, capital accumulation in the tradables sector results in an appreciation of the real exchange rate back toward steady state.

Grafe and Wyplosz (1999) similarly try to develop a theoretical model that can account for the main real exchange rate regularities observed during the transition. These authors, however, take a somewhat different approach as they distinguish three sectors: an "old" tradables sector, where output is produced by subsidized state-owned enterprises, a "new" tradables sector, and a "new" non-tradables (services) sector. Labor mobility out of the state sector is limited, with labor only moving if offered higher real wages by enterprises in the new sectors. Initially, the real exchange rate (real wages) needs to be sufficiently low to have the new tradables sector generate high enough profit margins to accumulate capital. Thereafter, a continuous real appreciation is required to make labor move out of the state sector. As labor reallocates, the state sector is forced to raise productivity by closing down inefficient production lines. Contrary to the mechanism underlying the Balassa-Samuelson model, in the Grafe and Wyplosz model rising productivity in the tradables sector is a response to a real appreciation, rather than being the driving force behind it.

\section{ANALYTICAL FraMEWORK}

To identify the factors that underlie real exchange rate movements, it is useful to decompose the aggregate price level into its traded and non-traded components, both home and abroad as (see, for instance, MacDonald, 1998):

$$
\begin{aligned}
& p_{t}=\alpha_{t} p_{t}^{T}+\left(1-\alpha_{t}\right) p_{t}^{N T}, \\
& p_{t}^{*}=\alpha_{t}^{*} p_{t}^{T^{*}}+\left(1-\alpha_{t}^{*}\right) p_{t}^{N T^{*}},
\end{aligned}
$$


where $p_{t}{ }^{T}$ denotes the price of traded goods, $p_{t}{ }^{N T}$ denotes the price of non-traded goods and the $\alpha$ 's denote the share of traded goods in each economy.

The external real exchange rate with respect to overall prices, $q_{t}$, can be defined as the ratio of the aggregate domestic price level to the aggregate foreign price level, measured in a common currency:

$$
q_{t} \equiv s_{t}+p_{t}-p_{t}^{*}
$$

where s denotes the nominal exchange rate expressed in units of the foreign currency per unit of the domestic currency. The external real exchange rate with respect to the price of tradables, $q_{t}^{T}$, can be defined in a similar way:

$$
q_{t}^{T} \equiv s_{t}+p_{t}^{T}-p_{t}^{T^{*}}
$$

Finally, the internal real exchange rates, $r_{t}$ and $r_{t}^{*}$, can be expressed as the ratio of the domestic price of tradables to that of nontradables within each country:

$$
\begin{aligned}
& r_{t}=p_{t}^{T}-p_{t}^{N T}, \\
& r_{t}^{*}=p_{t}^{T^{*}-p_{t}^{N T^{*}}} .
\end{aligned}
$$

By combining these terms, the external real exchange rate with respect to general prices can be rewritten as a combination of the external real exchange rate for tradables and a weighted average of the internal real exchange rate at home and abroad:

$$
q_{t}=q_{t}^{T}-\left(1-\alpha_{t}\right) r_{t}+\left(1-\alpha_{i}^{*}\right) r_{t}^{*}
$$

If it is assumed that purchasing power parity in levels holds for tradables, the first term on the right hand side of (5) is equal to zero or, under less restrictive assumptions, a constant. Under the additional assumptions that (i) returns to scale in production are constant, (ii) factors are fully mobile between the tradables and nontradables sectors, and (iii) capital markets are integrated internationally with real interest parity holding, the relative price of tradables (the internal real exchange rate) will be proportional to the productivity differential between the nontradables and tradables sectors both at home and abroad:

$$
\begin{aligned}
& r_{t}=-a_{t}^{T}+a_{t}^{N T}, \\
& r_{t}^{*}=-a_{t}^{T^{*}}+a_{t}^{N T^{*}},
\end{aligned}
$$

where $\mathrm{a}_{t}{ }^{T}$ denotes total productivity in the tradables sector, and $\mathrm{a}_{t}{ }^{N T}$ denotes that in the nontradables sector in each economy. 
Given these assumptions, countries where tradables productivity relative to nontradables productivity is higher at home than abroad will have a lower domestic price of tradables relative to nontradables and an appreciated real exchange rate (a higher ratio of the aggregate domestic price level relative to the aggregate foreign price level). By substituting (6) and (6') in (5) an expression for the real exchange rate in terms of productivity differentials is obtained:

$$
q_{t}=q_{t}^{T}+\left(1-\alpha_{t}\right)\left(a_{t}^{T}-a_{t}^{N T}\right)-\left(1-\alpha_{t}^{*}\right)\left(a_{t}^{T^{*}}-a_{t}^{N T^{*}}\right) \text {. }
$$

This productivity-based view of the level of the real exchange rate was first emphasized by Balassa (1964) and Samuelson (1964). Equation 7 will not have an empirical counterpart, however, if the restrictive assumptions that underlie its derivation are not satisfied. For instance, if purchasing power parity does not hold for tradables or international capital is less than fully mobile, demand side factors will also have a role in determining the relative price of tradables versus nontradables. In practice, the real exchange rate can be expected to reflect, in addition to domestic supply-side factors, such factors as the level and composition of government spending, the terms of trade facing the domestic economy, the country's net foreign asset position, real interest rate levels, and the degree of openness to trade. ${ }^{6}$ We will now turn to an empirical investigation of the productivity-based view of the real exchange rate.

\section{The Cross-Sectional Dimension}

The Balassa-Samuelson model implies that countries with a relatively low ratio of tradables to nontradables productivity will have a depreciated real exchange rate (a relatively low domestic price level). This can be assessed by calculating the gap between a purchasing power paritybased U.S. dollar exchange rate and the nominal U.S. dollar exchange rate. The purchasing power parity-based exchange rate measures how many goods the domestic currency buys within the country relative to the U.S. as numéraire country, while the nominal U.S. dollar exchange rate measures how many U.S. dollars the domestic currency buys in the foreign exchange market. ${ }^{7}$ If Balassa-Samuelson holds, the gap between the two exchange rates will tend to be larger the lower real GDP per capita measured in purchasing power parity terms is. Using World Bank data for a sample of non-transition countries in 1999, Figure 2 shows the positive relationship between the exchange rate gap-measured in ratio terms-and PPP per capita GDP that is obtained from a simple linear regression (t-values in parentheses): ${ }^{8}$

\footnotetext{
${ }^{6}$ A theoretical justification for the inclusion of these kinds of variables is provided in Mussa (1984) and Frenkel and Mussa (1985).
}

${ }^{7}$ The ratio between the two exchange rates can therefore be interpreted as a ratio measuring the cost of goods in the domestic economy relative to the cost in the United States (the numerraire country) using the U.S. dollar as numéraire.

${ }^{8}$ The exchange rate ratio data are based on the 1996 round of surveys from the International Comparison Programme (additional details are provided in the data appendix). There are 149 countries in the sample, ranging from low to high income countries. The estimation results 
$\log ($ Exchange rate ratio $)=-1.86+0.41 * \log ($ PPP GDP per capita $)$
$\mathrm{R}^{2}=0.63$
S.E. $=0.16$

(18.78) (15.39)

A coefficient of 0.41 suggests that for these non-transition countries, an increase in PPP per capita GDP by one percent leads to an increase in the exchange rate ratio, and hence a real exchange rate appreciation, by 0.41 percent. In particular, when a lower-income country pegs its currency at a fixed rate to that of a higher-income country (group of countries), income convergence is likely to be associated with a positive inflation differential, with one percent higher growth expected to be reflected in 0.41 percent higher inflation. The 0.41 elasticity reflects the simple linear specification that underlies equation 8 . However, from Figure 2 it is difficult to see which alternative specification would be able to catch any non-linearities that may be present in the data. Moreover, similar estimates are obtained for this elasticity when the simple cross-section regression is re-estimated for each year from 1991 to 1999.

The country sample underlying the estimation of Equation 8 does not include the transition economies. However, estimates of the relationship between the exchange rate gap and the per capita GDP level that are derived from a large sample of non-transition economies provide a benchmark for the transition economies. It can be surmised that this relationship would also have held in these economies if they had operated under a regime governed by market forces. Reflecting the heavy distortions induced by central planning, including those stemming from exchange rate controls, the exchange rate gaps at the beginning of the transition were, however, quite different from those in market economies at comparable levels of development. As the transition proceeded and the distortions from central planning were being eliminated, the transition economies ceased gradually to be outliers.

To analyze how real exchange rates in the transition countries have moved relative to the rest of the world, these countries' exchange rate gaps have been plotted against the corresponding per capita GDP levels for the years 1993 and 1999. ${ }^{9}$ The arrows in Figure 3 (EU accession countries) and Figure 4 (remaining transition countries) show the movement during the 6-year intermediate period. To allow a comparison with the rest of the world, the line estimated in equation 8 and lines for plus/minus one standard deviation are added to both figures. ${ }^{10}$

change little if the 51 nonbenchmark countries, the International Comparison Programme data for which are regression-based, are excluded from the analysis.

${ }^{9} 1993$ was chosen as initial year since by that time exchange rates had become marketdetermined in most transition countries.

${ }^{10}$ The upper confidence interval is calculated as ((constant + standard deviation) + (coefficient + one standard deviation)* $\log ($ PPP GDP)), and similarly with the lower confidence interval. 
Figures 3 and 4 clearly illustrate the large differences in transition experiences, with a number of distinct patterns emerging. First, and most strikingly, all transition economies (with the exception of Turkmenistan) have moved closer to the line that represents the relationship between the exchange rate gap and the per capita GDP level in the non-transition countries. Second, most EU accession countries have moved in the North-East direction while the remaining transition countries (mainly those of the former Soviet Union) have moved in the North-West direction.

Figures 3 and 4 also indicate that in case of the EU accession countries, the movement toward the line representing the non-transition countries has been associated with an increase in per capita income, whereas for other transition countries (mainly those from the former Soviet Union) this movement has been associated with a fall in per capita income levels. This finding suggests that, in spite of divergent growth and productivity developments, the initial exchange rate misalignment has tended to narrow in both groups of countries.

The Visegrad countries (Czech Republic, Hungary, Poland, and Slovak Republic) and Slovenia have essentially moved parallel with the estimated line, and they are now either inside or very close to the confidence intervals. Hence, their exchange rate gap is similar to that observed in non-transition countries at comparable levels of development. The same also holds for the Baltics, which over this period have made a major jump from far outside the confidence intervals in 1993 to within the confidence intervals in 1999. While catching up further with the income levels of the advanced economies, these transition countries can be expected to have a real exchange rate appreciation.

Quantitatively, the size of the appreciation can be expected to be broadly the same as that found for the non-transition countries. A narrowing of the income gap by one percent will therefore tend to be associated with a 0.4 percent real exchange rate appreciation. In case these more advanced transition economies peg their currencies to the Euro, this effect will translate in higher inflation in the process of catching-up with income levels in the current EU members. This should be taken into account assessing the candidate countries' ability to comply with the Maastricht inflation criteria. ${ }^{11}$

\section{TIME SERIES Estimation}

The analysis in section III indicates that across the world's advanced and developing economies a positive relationship holds between the level of income per capita and the exchange rate gap. This positive relationship implies that an increase in income will be associated with a narrowing of the gap between the dollar exchange rate and the PPP exchange

\footnotetext{
${ }^{11}$ According to these criteria, one year prior to joining EMU, the candidate country's rate of inflation should not be more than $1 \frac{1}{2}$ percentage point higher than the average rate of inflation in those three EU countries where inflation is the lowest. See, for instance, Begg, Halpern, and Wyplosz (1999) and Szapáry (2000) on this issue.
} 
rate, and it provides strong cross-sectional evidence in support of the Balassa-Samuelson hypothesis.

To find additional time-series evidence in support of the hypothesis, the remainder of the paper will test directly the presence of Balassa-Samuelson-type effects in two groups of transition countries, i) the EU accession countries (seven central and eastern European countries and the Baltics), and ii) the other transition countries in the sample (southeastern European countries, Russia and the other countries of the former Soviet Union, and Mongolia). This will be done by regressing real exchange rates on different measures of productivity in the tradable and nontradable sectors during the period 1991 to 1998 . If an increase in productivity in the tradable sector implies an appreciation of the exchange rate, this can be interpreted as evidence in support of the Balassa-Samuelson effect.

Equation 7 provides a broad framework for testing the Balassa-Samuelson effect, but a number of additional steps need to be taken to make this framework empirically implementable. First, since the geographical composition of the transition countries' trade is diversified, a tradeweighted effective exchange rate has to be used. For our estimation purposes, the tradeweighted real effective exchange rates calculated by the IMF are employed (see also the Appendix for a full description of the data used). One limitation of this approach is that it is based on constant weights, even though trade patterns continued to shift significantly throughout the transition. Second, the tradables and nontradables sectors need to be defined. Reflecting data availability, the tradable sector comprises industry and construction (the secondary sector), while the nontradable sector is defined as services (the tertiary sector). The agricultural (primary) sector is kept separate since it typically is a mixture of tradable and nontradable activities (the Balassa-Samuelson model does not predict any particular relationship between productivity in agriculture and the real exchange rate). Third, observations for the transition countries need to be scaled relative to those for the rest of the world, since, as can be seen from equation 7, the Balassa-Samuelson effect is driven by productivity developments relative to the rest of the world. To simplify the data construction process, rather than using the same weighting scheme that underlies the construction of the real effective exchange rates, the rest of the world is proxied by an average of OECD countries, calculated on the basis of each OECD member's share in total 1996 OECD exports. ${ }^{12}$

Estimating the framework provided by equation 7 in addition requires specifying the explanatory variables. Total factor productivity is proxied by average labor productivity in the three main sectors. Using this proxy does not introduce a bias to the extent the marginal product of labor is proportional to its average product in both the tradables and nontradables

12 This has the advantage of giving a higher weight to open European countries that are proximate to the transition countries than would occur if (say) GDP weights were used. 
sectors, which is the case under relatively mild conditions (Canzoneri et al., 1999). ${ }^{13}$ To construct the labor productivity data, output and employment data were collected on a sectoral basis for the period 1991-98 for 25 transition countries and the OECD countries. ${ }^{14}$ Figure 2 shows for each country the effective exchange rate vis-à-vis productivity in the secondary sector.

To control for broad macroeconomic developments that affect real exchange rate movements, additional explanatory variables are included in the regression. These additional variables in part intend to capture movements off an equilibrium path that is mainly determined by productivity developments. As discussed above, deviations from equilibrium were particularly pronounced in the early transition years. The money-to-GDP ratio captures monetary shocks that, in combination with nominal rigidities, translate into real exchange rate movements. The government balance reflects the impact of fiscal policy on the real exchange rate through changes in the relative demand for nontradables. The degree of openness of the economy determines by how much the real exchange rate responds to monetary and real shocks (the response is larger in more closed economies). The terms of trade and fuel prices and nonfuel prices, finally, affect the trade balance and the relative demand for non-tradables. As discussed above, all the explanatory variables-except fuel and nonfuel prices-are calculated relative to an average of OECD countries. Logarithms are taken of all variables, and the estimated equation is therefore specified as follows:

$\log ($ Real effective exchange rate $)=$ $\alpha_{0, i}+$ $\alpha_{1}{ }^{*} \log ($ an index for the productivity level in the agricultural sector relative to the same variable for the OECD countries) +

$\alpha_{2}{ }^{*} \log ($ an index for the productivity level in the industrial sector relative to the same variable for the OECD countries) + $\alpha_{3}{ }^{*} \log ($ an index for the productivity level in the services sector relative to the same variable for the OECD countries) + $\alpha_{4^{*}} \log ($ broad money divided by GDP relative to the same variable for the OECD)+ $\alpha_{5}{ }^{*} \log$ (openness of the economy relative to openness of OECD economies)+ $\alpha_{6}{ }^{*} \log$ (government balance relative to government balance of OECD economies)+ $\alpha_{7}{ }^{*} \log ($ terms of trade relative to terms of trade of OECD economies) + $\alpha_{8}{ }^{*} \log ($ index for fuel prices) + $\alpha_{7}^{*} \log ($ index for nonfuel prices),

${ }^{13}$ Evidence for the Baltics, and Russia and the other countries of the former Soviet Union suggests that total factor productivity and average labor productivity moved closely together in the initial transition years (De Broeck and Koen, 2000).

${ }^{14}$ For some of the countries the series is somewhat shorter, while for the EU accession countries also 1999 data were collected. In the appendix a complete list of countries and data sources is provided. 
where the constant term $\alpha_{0, \mathrm{i}}$ is allowed to differ between the countries, $\mathrm{i}$, that are included in the sample.

Different estimation methods are available to estimate equation 9 using a panel. One approach is to estimate a simple static fixed effects model, where the slope coefficients are assumed to be similar and a different constant-fixed effect-is included for each country. If the variables are non-stationary, however, other estimators may be more efficient. Furthermore, in the presence of dynamic effects and slope heterogeneity, the use of standard panel techniques, such as the fixed effect estimator, may lead to inconsistent estimates and potentially misleading inferences, even for large $\mathrm{N}$ and $\mathrm{T}$ panels. Under these conditions, other methods that can estimate the long-run relationship include the Mean Group estimator and the Pooled Mean Group estimator. The former estimates separate equations for each group and examines the distribution of the estimated coefficients across groups. Pesaran and Smith (1995) show that the Mean Group estimator will produce consistent estimates of the average of the parameters. This estimator, however, does not take into account the fact that certain parameters may be the same across groups. At the other extreme are the traditional pooled estimators, such as the fixed and random effects estimators, where the intercepts are allowed to differ across groups while all other coefficients and error variances are constrained to be the same. This paper considers an intermediate estimator, which is called the Pooled Mean Group because it involves both pooling and averaging (Pesaran, Shin, and Smith, 1999). This estimator allows the intercepts, short-run coefficients and error variances to differ freely across groups, but constrains the long-run coefficients to be the same. There are often good reasons to expect the long-run equilibrium relationships between variables to be similar across groups, while the reasons for assuming that short-run dynamics and error variances should be the same tend to be less compelling.

Table 1 shows the fixed effect estimation for the three groups of countries. There are several interesting results. First, the tradables productivity variable becomes significant for both EU accession countries and the other transition countries. This suggests that an increase in tradables productivity in the transition countries relative to the OECD countries implies an appreciation in the former's real effective exchange rate. For the EU accession countries, this result corresponds to the data pattern in Figure 1, where tradables productivity is positively correlated with an appreciation of the exchange rate. However, for the other transition countries, this significant relationship reflects a fall in tradables productivity which is associated with a depreciation of the effective exchange rate. Both developments can be explained in terms of the Balassa-Samuelson model, which predicts that, irrespective of their direction, changes in productivity in the tradable sector will affect the real effective exchange rate. Moreover, for the EU accession countries, the nontradables productivity variable is clearly significant with the expected negative sign.

Turning to the variables other than those measuring productivity developments, the money-to GDP-ratio is only significant for the other transition countries, where, during the initial transition years, sharp nominal exchange rate depreciations were typically associated with massive monetary expansions. Openness and the government balance become significant for 
the EU accession countries, and also for the OECD countries, while commodity prices are significant for the other transition countries, reflecting commodity-dominated trade patterns in Russia and some other countries of the former Soviet Union. The terms of trade variable is not significant in either group of transition countries. ${ }^{15}$

As a robustness check, in Table 2 the tradables productivity variable is defined as a ratio to nontradables productivity. The results generally confirm those in Table 1 . One key difference is that the productivity variable is now only significant for the EU accession countries but not for the other transition countries. In other words, there appears to be robust evidence of a Balassa-Samuelsson effect in central and eastern Europe and the Baltics but not in the other transition countries in the sample.

To test further the robustness of this conclusion a different panel estimator is introduced, which takes into consideration the fact that the series may be non-stationary. Tables 3 to 10 present the results from the Pooled Mean Group estimator, which imposes common long-run coefficients. ${ }^{16}$ Tables 3 and 4 show that the coefficient on the productivity variable is clearly significant with the expected sign for the EU accession countries. The coefficients are significantly lower than in the fixed effects estimation, reflecting the fact that the latter's coefficients capture both the long and the short-run effects. The error correction (or adjustment) coefficient is significant and it has the expected negative sign. Imposing long-run homogeneity reduces the standard errors of the long-run coefficients but does not change the coefficient estimates very much. This is confirmed by the Hausman test statistic, which is $\mathrm{X}^{2}(2)$ under the null hypothesis of no difference between the Pooled Mean Group and Mean Group estimator described above. The test is rejected in both cases and hence there is no significant difference between coefficients of the Pooled Mean Group estimator and the Mean Group estimator.

For the other transition countries, the results (Table 5 and 6) are not very different. In these regressions, the money-to-GDP variable is included as a control variable to capture the effects of sharp monetary expansions during the initial sample period. The coefficient of the productivity variable is clearly significant, indicating again the existence of a BalassaSamuelson effect. However, as discussed above, in this group of countries, a fall in tradables

${ }^{15}$ The terms of trade variable is only significant for the OECD countries, reflecting the more stable economic environment in these countries during the sample period. As a result, the terms of trade variable is not dominated by other explanatory variables that tend to capture macroeconomic and structural developments typically associated with the transition. In the longer run, when the process of structural adjustment has come to completion, it can be expected that the terms of trade will also be important for the transition countries.

${ }^{16}$ The Pooled Mean Group estimation was carried out in Gauss using a program made available on http://www.econ.cam.ac.uk/faculty/pesaran. The program allows the user to select the proper lag order of the autoregressive distributive lag (ARDL) model. 
productivity has been associated with a depreciating exchange rate. As these countries return to positive output growth and productivity begins to pick up again, a Balassa-Samuelson effect operating in the opposite direction is likely to emerge.

To check the robustness of the estimates for the EU accession countries, various control variables (government balance relative to OECD and openness of economy relative to OECD) were included in the regression. As can be seen from Tables 7 to 10 , the results do not change much. The productivity variable continues to be significant, while the control variables are not. Furthermore, data for 1999 is now available for central and eastern Europe and the Baltics and adding this extra year does not change the results; for example the estimated elasticity in Table 3 remains significant and changes from 0.308 to 0.325 .

The coefficients from these time-series regressions lie in the range between 0.2 and 0.6 which largely seems consistent with the coefficient of 0.41 found in the cross-sectional estimations above. This broadly confirms the finding that an increase in the relative productivity differential of one percent leads to an increase in the exchange rate of approximately 0.4 percent, which for a fixed exchange rate implies an increase in inflation to the tune of 0.4 percent.

Using this elasticity the average contribution to inflation from the Balassa-Samuelsson effect in different central and eastern European and Baltic countries in 1999 was approximately one percentage point (calculated using the average productivity growth rate in 1999 for all countries). Countries with high productivity growth rates (Bulgaria, Hungary, Poland, Romania, and the Slovak Republic) obviously have had a higher effect than those with lower productivity growth rates (the Czech Republic, Estonia, Latvia, Lithuania, and Slovenia).

\section{Conclusions}

A number of transition countries have experienced strong real exchange rate appreciations as the initial transformational recession has given way to a recovery. This paper has used data from a range of transition countries to address the question as to whether these appreciations reflected misalignment or were the result of an equilibrium adjustment induced by the movement toward a market-based economy. The results of the analysis suggest that there is clear evidence of productivity-based exchange rate movements (or Balassa-Samuelson effects) in the EU accession countries. But the evidence is more tentative in the other transition countries, Russia and the other countries of the former Soviet Union in particular. Most of these countries have only recently entered the recovery phase and have not yet experienced extended periods of productivity growth. However, the analysis tentatively suggests that as these countries embark on a path of sustained growth, they will also experience real exchange rate appreciations.

These results have important policy implications. Real exchange rate appreciations that reflect productivity gains in the tradable sector are an equilibrium phenomenon and do not erode competitiveness. In the transition economies, these appreciations reflect progress in their becoming full-fledged market economies, and they do not require a policy response. The 
empirical analysis suggests that while exchange rates in most EU accession countries have moved broadly toward equilibrium from an initial out-of-equilibrium position, there is scope for further equilibrium real appreciation. For accession countries which have their currencies pegged to the euro, this appreciation will take the form of higher inflation than in the EMU member countries, with implications for the Maastricht inflation criteria. In the transition countries other than the EU accession countries, real exchange rate appreciations in the second half of the 1990s in part still reflected an ongoing adjustment to initial undervaluations, but these countries can also be expected to begin to experience equilibrium appreciations in tandem with productivity gains. 
Table 1. Explaining Movements in the Real Effective Exchange Rate, 1993-1998 1/

\begin{tabular}{|c|c|c|c|c|c|c|}
\hline & \multicolumn{2}{|c|}{ Eastern Europe 2/ } & \multicolumn{2}{|c|}{$\begin{array}{c}\text { Other transition } \\
\text { countries } 3 /\end{array}$} & \multicolumn{2}{|c|}{ OECD countries $4 /$} \\
\hline $\begin{array}{l}\text { Productivity in } \\
\text { agriculture }\end{array}$ & $\begin{array}{c}\text { All } \\
\mathbf{0 . 2 2} \\
(2.15)\end{array}$ & $\begin{array}{c}\text { Horserace } \\
\mathbf{0 . 2 6} \\
(2.87)\end{array}$ & $\begin{array}{c}\text { All } \\
0.12 \\
(0.58)\end{array}$ & Horserace & $\begin{array}{c}\text { All } \\
0.06 \\
(1.00)\end{array}$ & Horserace \\
\hline $\begin{array}{l}\text { Productivity in } \\
\text { industry }\end{array}$ & $\begin{array}{c}0.87 \\
(4.53)\end{array}$ & $\begin{array}{c}\mathbf{0 . 8 8} \\
(5.17)\end{array}$ & $\begin{array}{c}\mathbf{0 . 8 8} \\
(3.36)\end{array}$ & $\begin{array}{c}\mathbf{0 . 8 7} \\
(4.61)\end{array}$ & $\begin{array}{l}0.18 \\
(1.55)\end{array}$ & $\begin{array}{c}0.29 \\
(3.03)\end{array}$ \\
\hline $\begin{array}{l}\text { Productivity in } \\
\text { services }\end{array}$ & $\begin{array}{c}\mathbf{- 0 . 5 5} \\
(2.29)\end{array}$ & $\begin{array}{l}-\mathbf{0 . 7 3} \\
(3.88)\end{array}$ & $\begin{array}{c}0.10 \\
(0.36)\end{array}$ & & $\begin{array}{c}0.17 \\
(1.02)\end{array}$ & \\
\hline $\begin{array}{l}\text { Money over } \\
\text { GDP }\end{array}$ & $\begin{array}{l}-0.11 \\
(1.28)\end{array}$ & & $\begin{array}{c}-0.31 \\
(3.43)\end{array}$ & $\begin{array}{c}\mathbf{- 0 . 3 4} \\
(5.31)\end{array}$ & $\begin{array}{c}0.02 \\
(0.30)\end{array}$ & \\
\hline Openness & $\begin{array}{l}\mathbf{- 0 . 4 0} \\
(4.12)\end{array}$ & $\begin{array}{l}\mathbf{- 0 . 4 1} \\
(4.85)\end{array}$ & $\begin{array}{l}-0.12 \\
(1.30)\end{array}$ & & $\begin{array}{c}-\mathbf{- 0 . 4 8} \\
(5.30)\end{array}$ & $\begin{array}{l}\mathbf{- 0 . 4 5} \\
(5.24)\end{array}$ \\
\hline $\begin{array}{l}\text { Government } \\
\text { balance }\end{array}$ & $\begin{array}{c}\mathbf{0 . 0 4} \\
(2.86)\end{array}$ & $\begin{array}{c}\mathbf{0 . 0 4} \\
(2.94)\end{array}$ & $\begin{array}{l}-0.02 \\
(0.92)\end{array}$ & & $\begin{array}{c}\mathbf{0 . 6 1} \\
(2.22)\end{array}$ & \\
\hline Terms of Trade & $\begin{array}{l}-0.03 \\
(0.18)\end{array}$ & & $\begin{array}{l}-0.15 \\
(1.39)\end{array}$ & & $\begin{array}{c}\mathbf{0 . 7 4} \\
(3.56)\end{array}$ & $\begin{array}{c}\mathbf{0 . 7 5} \\
(3.66)\end{array}$ \\
\hline Fuel & $\begin{array}{c}-0.02 \\
(0.17)\end{array}$ & & $\begin{array}{l}\mathbf{- 0 . 8 3} \\
(2.62)\end{array}$ & $\begin{array}{l}\mathbf{- 0 . 6 9} \\
(2.25)\end{array}$ & $\begin{array}{l}-0.01 \\
(0.22)\end{array}$ & \\
\hline Nonfuel & $\begin{array}{c}0.01 \\
(0.03)\end{array}$ & & $\begin{array}{c}2.43 \\
(2.86)\end{array}$ & $\begin{array}{c}\mathbf{2 . 0 8} \\
(2.67)\end{array}$ & $\begin{array}{c}0.12 \\
(1.08)\end{array}$ & \\
\hline $\mathrm{R}^{2}$ & 0.66 & 0.64 & 0.57 & 0.53 & 0.94 & 0.94 \\
\hline
\end{tabular}

1/ All variables are in logs and relative to the average for the OECD countries included in the analysis (except for the OECD countries themselves, where it is the levels); $t$-values in parentheses.

2/ Bulgaria, the Czech Republic, Estonia, Hungary, Latvia, Lithuania, Poland, the Slovak Republic, and Slovenia.

3/ Albania, Armenia, Azerbaijan, Belarus, Croatia, Georgia, Kazakhstan, Kyrgyz Republic, Macedonia, Moldova, Mongolia, Russia, Tajikistan, Turkmenistan, Ukraine, and Uzbekistan.

4/ Austria, Australia, Belgium, Canada, Denmark, Finland, France, Germany, Italy, Japan, the Netherlands, Norway, Portugal, Spain, Sweden, the United Kingdom, and the United States. 
Table 2. Explaining Movements in the Real Effective Exchange Rate, 1993-1998 1/

\begin{tabular}{|c|c|c|c|c|c|c|}
\hline \multirow[b]{2}{*}{$\begin{array}{l}\text { Productivity in } \\
\text { agriculture }\end{array}$} & \multicolumn{2}{|c|}{ Eastern Europe 2/ } & \multicolumn{2}{|c|}{$\begin{array}{l}\text { Other transition } \\
\text { countries } 3 /\end{array}$} & \multicolumn{2}{|c|}{ OECD countries $4 /$} \\
\hline & $\begin{array}{c}\text { All } \\
\mathbf{0 . 2 6} \\
(2.78)\end{array}$ & $\begin{array}{c}\text { Horserace } \\
\mathbf{0 . 2 7} \\
(3.08)\end{array}$ & $\begin{array}{c}\text { All } \\
0.33 \\
(1.47)\end{array}$ & Horserace & $\begin{array}{c}\text { All } \\
0.06 \\
(0.97)\end{array}$ & Horserace \\
\hline $\begin{array}{l}\text { Productivity in } \\
\text { industry/ } \\
\text { Productivity in } \\
\text { services }\end{array}$ & $\begin{array}{c}\mathbf{0 . 7 8} \\
(4.22)\end{array}$ & $\begin{array}{c}\mathbf{0 . 8 2} \\
(5.27)\end{array}$ & $\begin{array}{c}0.46 \\
(1.77)\end{array}$ & & $\begin{array}{c}0.12 \\
(0.98)\end{array}$ & \\
\hline $\begin{array}{l}\text { Money over } \\
\text { GDP }\end{array}$ & $\begin{array}{l}-0.04 \\
(0.51)\end{array}$ & & $\begin{array}{c}-\mathbf{- 0 . 3 0} \\
(3.09)\end{array}$ & $\begin{array}{l}-\mathbf{- 0 . 3 6} \\
(5.47)\end{array}$ & $\begin{array}{c}0.06 \\
(0.61)\end{array}$ & \\
\hline Openness & $\begin{array}{l}-\mathbf{- 0 . 4 0} \\
(4.11)\end{array}$ & $\begin{array}{l}-0.41 \\
(4.87)\end{array}$ & $\begin{array}{l}-0.17 \\
(1.70)\end{array}$ & & $\begin{array}{l}-0.44 \\
(4.76)\end{array}$ & $\begin{array}{l}-0.33 \\
(4.14)\end{array}$ \\
\hline $\begin{array}{l}\text { Government } \\
\text { balance }\end{array}$ & $\begin{array}{c}\mathbf{0 . 0 4} \\
(3.24)\end{array}$ & $\begin{array}{c}\mathbf{0 . 0 4} \\
(3.54)\end{array}$ & $\begin{array}{l}-0.04 \\
(1.38)\end{array}$ & & $\begin{array}{c}\mathbf{0 . 8 6} \\
(3.27)\end{array}$ & $\begin{array}{c}\mathbf{0 . 8 9} \\
(3.70)\end{array}$ \\
\hline Terms of Trade & $\begin{array}{c}0.02 \\
(0.13)\end{array}$ & & $\begin{array}{l}-0.01 \\
(0.06)\end{array}$ & & $\begin{array}{c}\mathbf{0 . 7 5} \\
(3.46)\end{array}$ & $\begin{array}{c}\mathbf{0 . 7 9} \\
(3.68)\end{array}$ \\
\hline Fuel & $\begin{array}{l}-0.01 \\
(0.12)\end{array}$ & & $\begin{array}{l}-0.55 \\
(1.62)\end{array}$ & & $\begin{array}{l}-0.04 \\
(0.84)\end{array}$ & \\
\hline Nonfuel & $\begin{array}{l}-0.01 \\
(0.02)\end{array}$ & & $\begin{array}{c}1.29 \\
(1.48)\end{array}$ & & $\begin{array}{c}0.16 \\
(1.42)\end{array}$ & \\
\hline $\mathrm{R}^{2}$ & 0.64 & 0.63 & 0.47 & 0.38 & 0.94 & 0.93 \\
\hline
\end{tabular}

1/ All variables are in logs and relative to the average for the OECD countries included in the analysis (except for the OECD countries themselves, where it is the levels); $t$-values in parentheses.

2/ Bulgaria, the Czech Republic, Estonia, Hungary, Latvia, Lithuania, Poland, the Slovak Republic, and Slovenia.

3/ Albania, Armenia, Azerbaijan, Belarus, Croatia, Georgia, Kazakhstan, Kyrgyz Republic, Macedonia, Moldova, Mongolia, Russia, Tajikistan, Turkmenistan, Ukraine, and Uzbekistan.

4/ Austria, Australia, Belgium, Canada, Denmark, Finland, France, Germany, Italy, Japan, the Netherlands, Norway, Portugal, Spain, Sweden, the United Kingdom, and the United States. 
Table 3. Pooled Mean Group Estimates for Eastern Europe

Countries included in regression: Eastern Europe and the Baltics Model: ARDL $(1,1)$

Dependent variable:

Long run coefficient (t-statistic)

$\log ($ Real effective exchange rate)

Sample: 1991-1998

Log(productivity in industry sector relative

0.308 (4.58)

to OECD)

Error correction coefficient

$-0.643(3.91)$

Hausman test $\left(\mathrm{X}^{2}(1)\right.$-distributed)

$1.84(0.17)$

Note: Numbers in bold are significant at a five percent significance level. T-values in parenthesis except for the Hausman-test, which displays the p-value in the parenthesis.

Table 4. Pooled Mean Group Estimates for Eastern Europe

Countries included in regression: Eastern Europe and Baltics Model: ARDL $(1,1)$

Dependent variable:

$\log ($ Real effective exchange rate)

Long run coefficient (t-statistic)

Sample: 1991-1998

$\log$ (productivity in industry sector relative

$0.302(5.22)$

to OECD/productivity in service sector

relative to $\mathrm{OECD}$ )

Error correction coefficient

$-0.595(3.90)$

Hausman test $\left(\mathrm{X}^{2}(1)\right.$-distributed)

$1.04(0.31)$

Note: Numbers in bold are significant at a five percent significance level. T-values in parenthesis except for the Hausman-test, which displays the p-value in the parenthesis. 
Table 5. Pooled Mean Group Estimates for other Transition Countries

Countries included in regression: See footnote 3 in Table 2. Model: ARDL $(1,1,1)$

Dependent variable:

Log(Real effective exchange rate)

Long run coefficient (t-statistic)

Sample: 1991-1998

$\log$ (productivity in industry sector relative

$0.572(15.65)$ to OECD)

$\log$ (Money over GDP relative to OECD)

$-0.516(24.34)$

Error correction coefficient

Joint Hausman test $\left(X^{2}(2)\right.$-distributed)

$1.16(0.56)$

Note: Numbers in bold are significant at a five percent significance level. T-values in parenthesis except for the Hausman-test, which displays the p-value in the parenthesis.

Table 6. Pooled Mean Group Estimates for other Transition Countries

Countries included in regression: See footnote 3 in Table 2.

Model: ARDL $(1,1,1)$

Dependent variable:

Long run coefficient (t-statistic)

Log(Real effective exchange rate)

Sample: 1991-1998

Log(productivity in industry sector relative

$0.473(7.51)$

to $\mathrm{OECD}$ /productivity in service sector

relative to $\mathrm{OECD}$ )

$\log$ (Money over GDP relative to OECD)

$\mathbf{- 0 . 9 9 4}(43.00)$

Error correction coefficient

Joint Hausman test $\left(\mathrm{X}^{2}(2)\right.$-distributed)

$8.29(0.02)$

Note: Numbers in bold are significant at a five percent significance level. T-values in parenthesis except for the Hausman-test, which displays the p-value in the parenthesis. 
Table 7. Pooled Mean Group Estimates for Eastern Europe

Countries included in regression: Eastern Europe and Baltics Model: $\operatorname{ARDL}(1,1,1)$

Dependent variable:

$\log ($ Real effective exchange rate)

Long run coefficient (t-statistic)

Sample: 1991-1998

$\log$ (productivity in industry sector relative

$0.180(3.35)$ to $\mathrm{OECD}$ )

$\log ($ Government balance relative to $\mathrm{OECD})$

Error correction coefficient

$-\mathbf{0 . 5 2 8}(2.91)$

Joint Hausman test $\left(X^{2}(2)\right.$-distributed)

Note: Numbers in bold are significant at a five percent significance level. T-values in parenthesis except for the Hausman-test, which displays the p-value in the parenthesis.

Table 8. Pooled Mean Group Estimates for Eastern Europe

Countries included in regression: Eastern Europe and Baltics Model: ARDL $(1,1,1)$

Dependent variable:

Log(Real effective exchange rate)

Long run coefficient ( $t$-statistic)

Sample: 1991-1998

$\log$ (productivity in industry sector relative

to $\mathrm{OECD/productivity} \mathrm{in} \mathrm{service} \mathrm{sector}$

$0.278(4.26)$ relative to $\mathrm{OECD}$ )

$\log ($ Government balance relative to $\mathrm{OECD})$

$0.006(0.57)$

Error correction coefficient

-0.646 (4.98)

Joint Hausman test $\left(X^{2}(2)\right.$-distributed)

$3.37(0.19)$

Note: Numbers in bold are significant at a five percent significance level. T-values in parenthesis except for the Hausman-test, which displays the p-value in the parenthesis. 
Table 9. Pooled mean group estimates for Eastern Europe

Countries included in regression: Eastern Europe and Baltics Model: ARDL $(1,1,1)$

Dependent variable:

$\log ($ Real effective exchange rate)

Long run coefficient (t-statistic)

Sample: 1991-1998

Log(productivity in industry sector relative to OECD)

$0.514(13.67)$

$\log ($ Openness of economy relative to $-0.021(1.76)$ OECD)

Error correction coefficient

Joint Hausman test $\left(\mathrm{X}^{2}(2)\right.$-distributed) $2.63(0.27)$

Note: Numbers in bold are significant at a five percent significance level. T-values in parenthesis except for the Hausman-test, which displays the p-value in the parenthesis.

Table 10. Pooled Mean Group Estimates for Eastern Europe Countries included in regression: Eastern Europe and Baltics $\operatorname{ARDL}(1,1,1)$

Dependent variable:

$\log ($ Real effective exchange rate)

Long run coefficient (t-statistic)

Sample: $1991-1998$

$\log$ (productivity in industry sector relative

$0.473(12.99)$

to $\mathrm{OECD}$ /productivity in service sector relative to $\mathrm{OECD}$ )

$\log ($ Openness of economy relative to

OECD)

Error correction coefficient

Joint Hausman test $\left(X^{2}(2)\right.$-distributed) $1.12(0.57)$

Note: Numbers in bold are significant at a five percent significance level. T-values in parenthesis except for the Hausman-test, which displays the p-value in the parenthesis. 
Figure 1: Productivity in Industry and Real Effective Exchange Rate in Selected Countries

Czech Republic
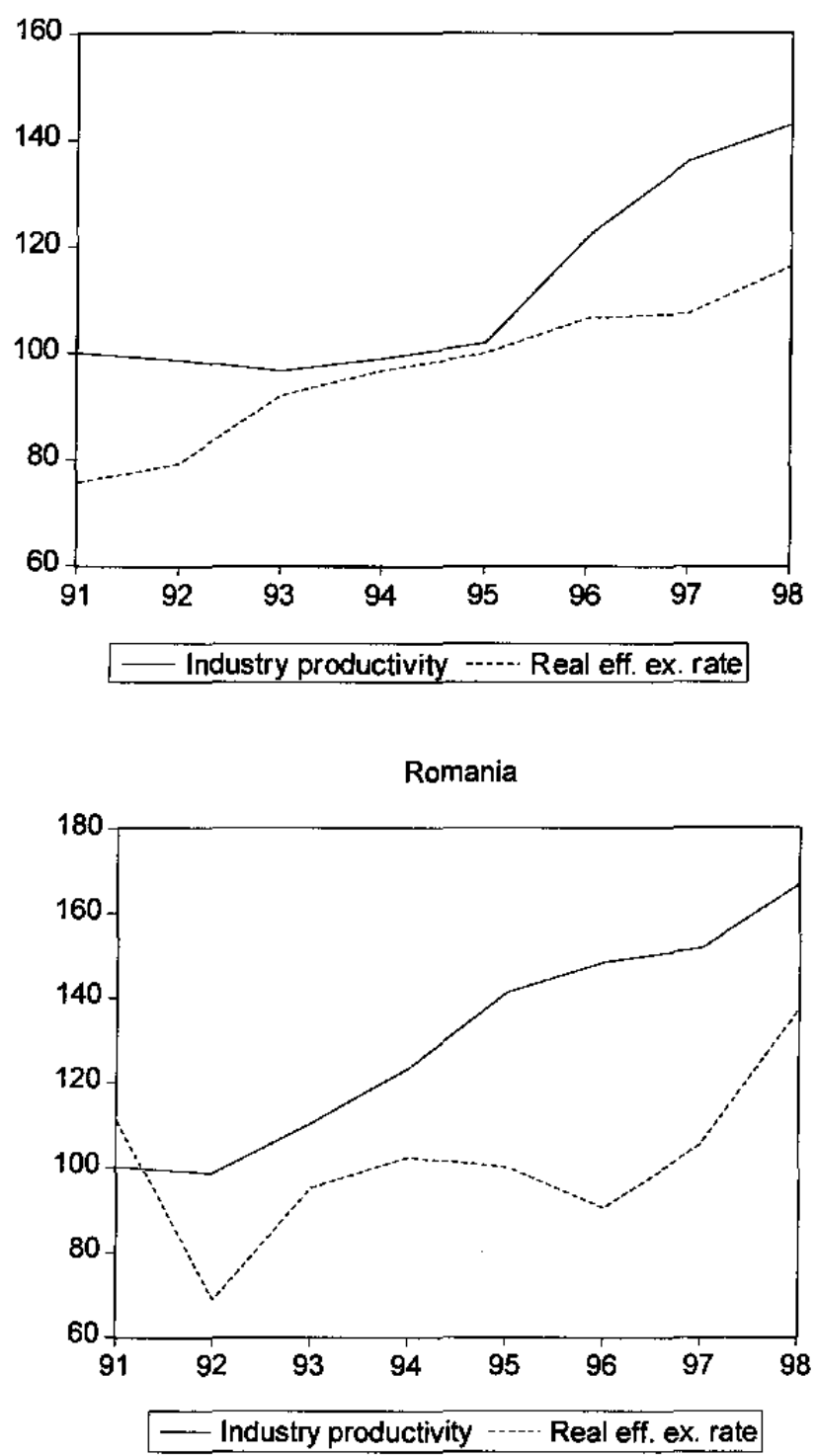

Hungary

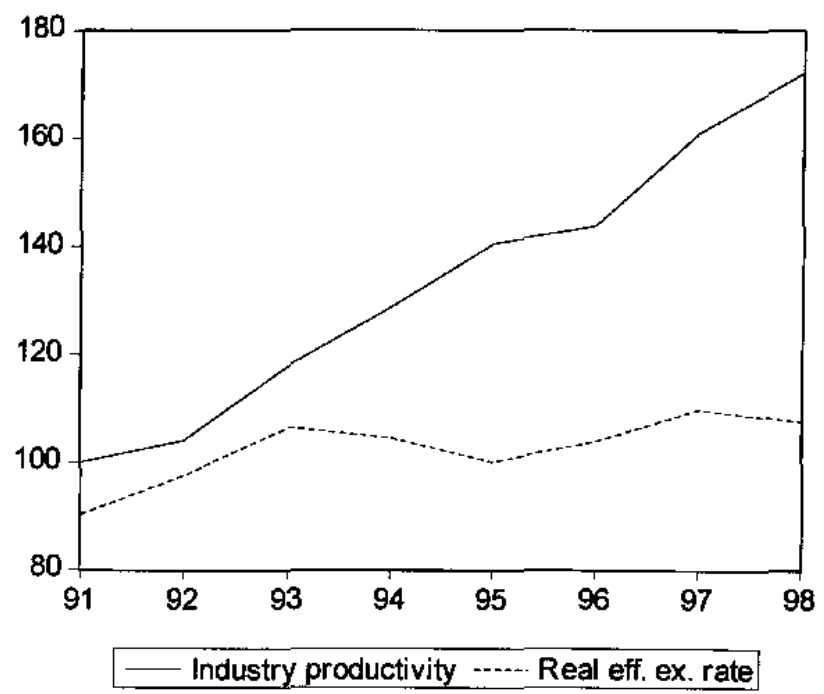

Poland

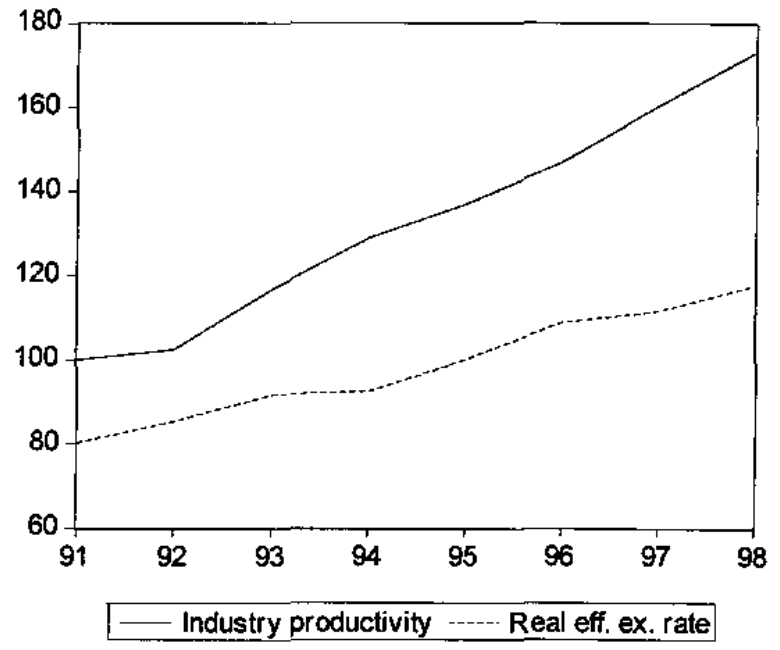


Figure 1. Productivity in Industry and Real Effective Exchange Rate in Selected Countries (Continued)
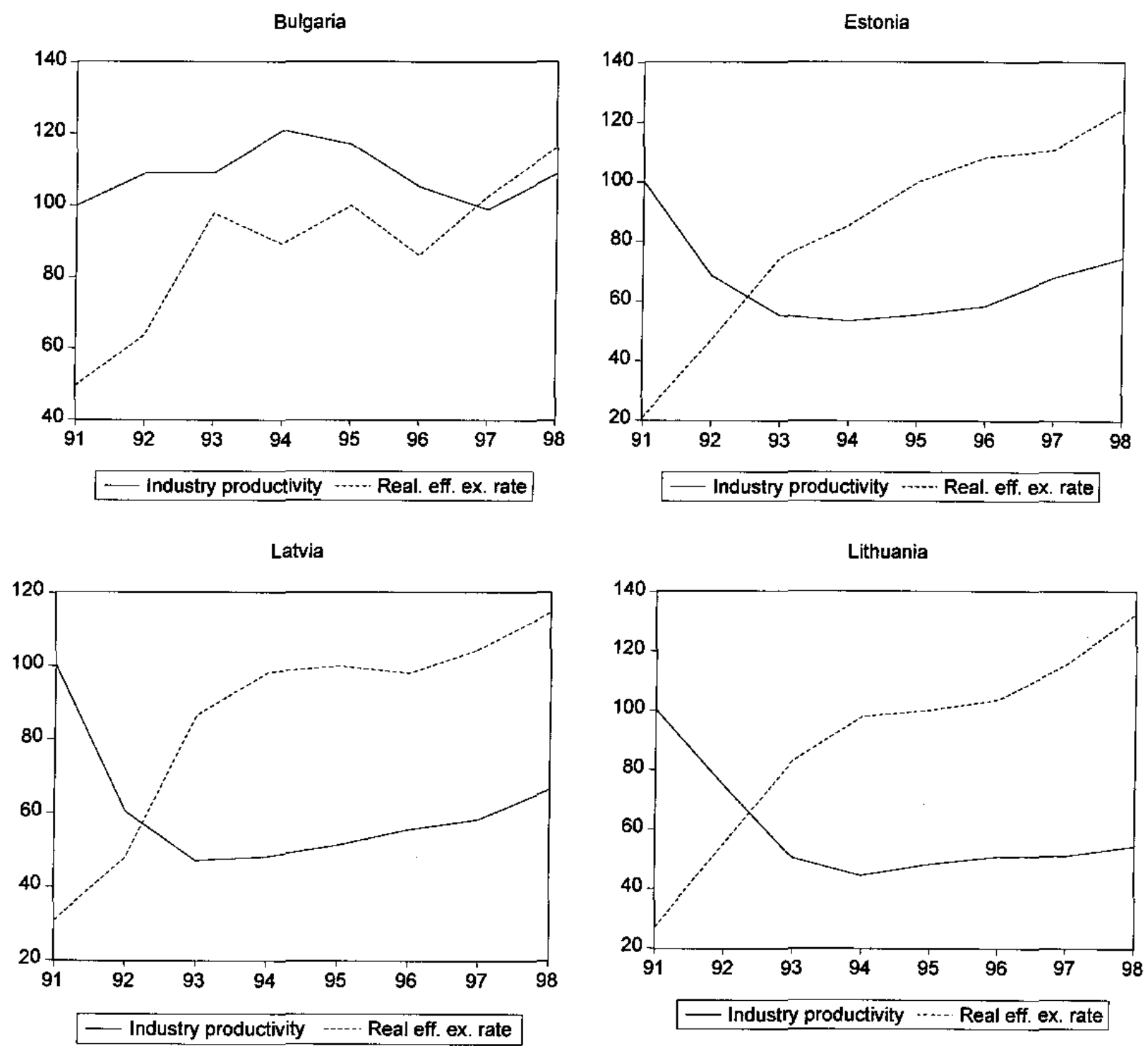
Figure 1. Productivity in Industry and Real Effective Exchange Rate in Selected Countries (Continued)
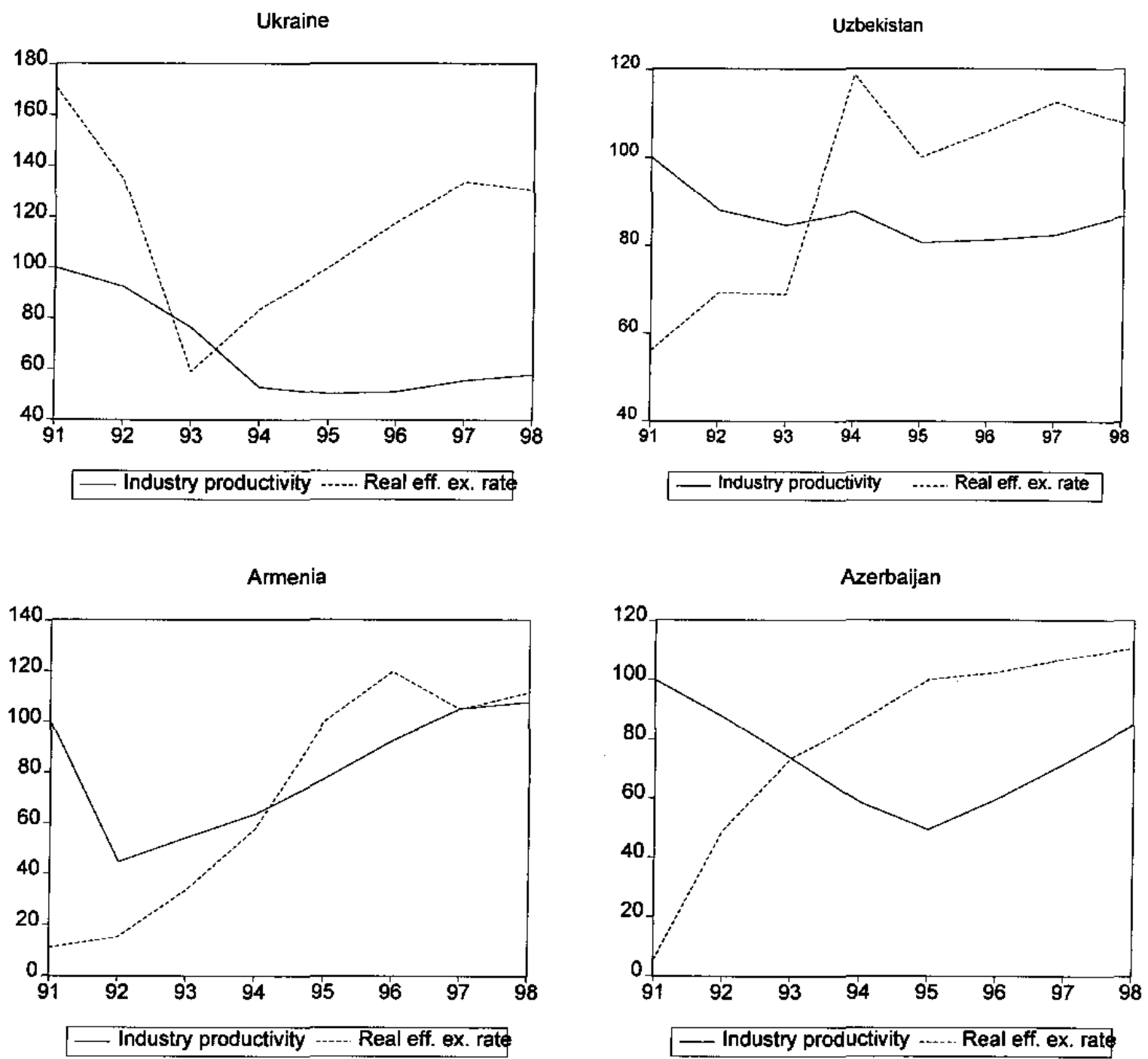
Figure 1. Productivity in Industry and Real Effective Exchange Rate in Selected Countries (Concluded)
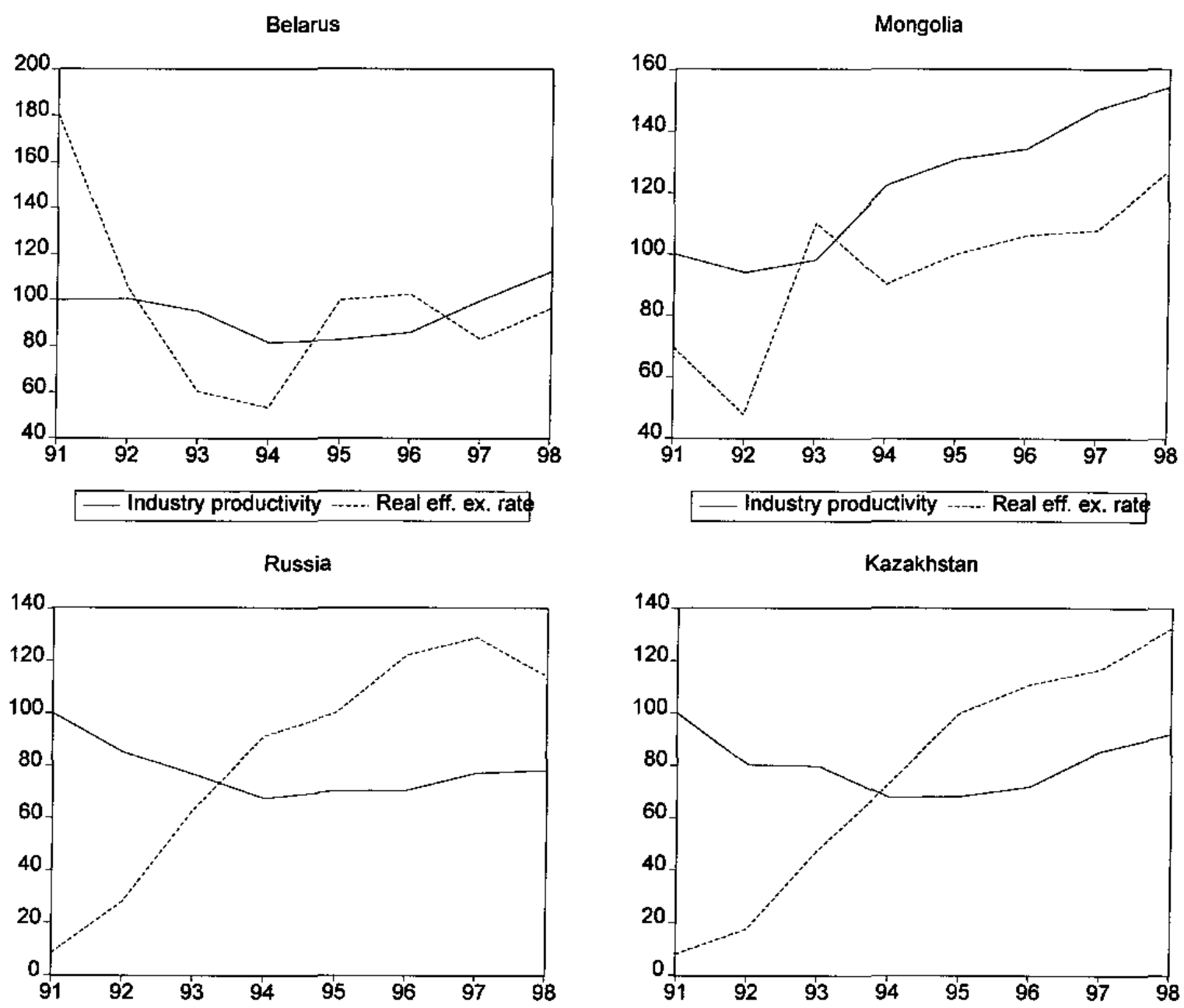

Industry productivity ....... Real eff. ex. rate

Industry productivity --.-. Real eff. ex. rate 
Figure 2. Exchange Rate Gap and Income Level for the World Excluding Transition Countries

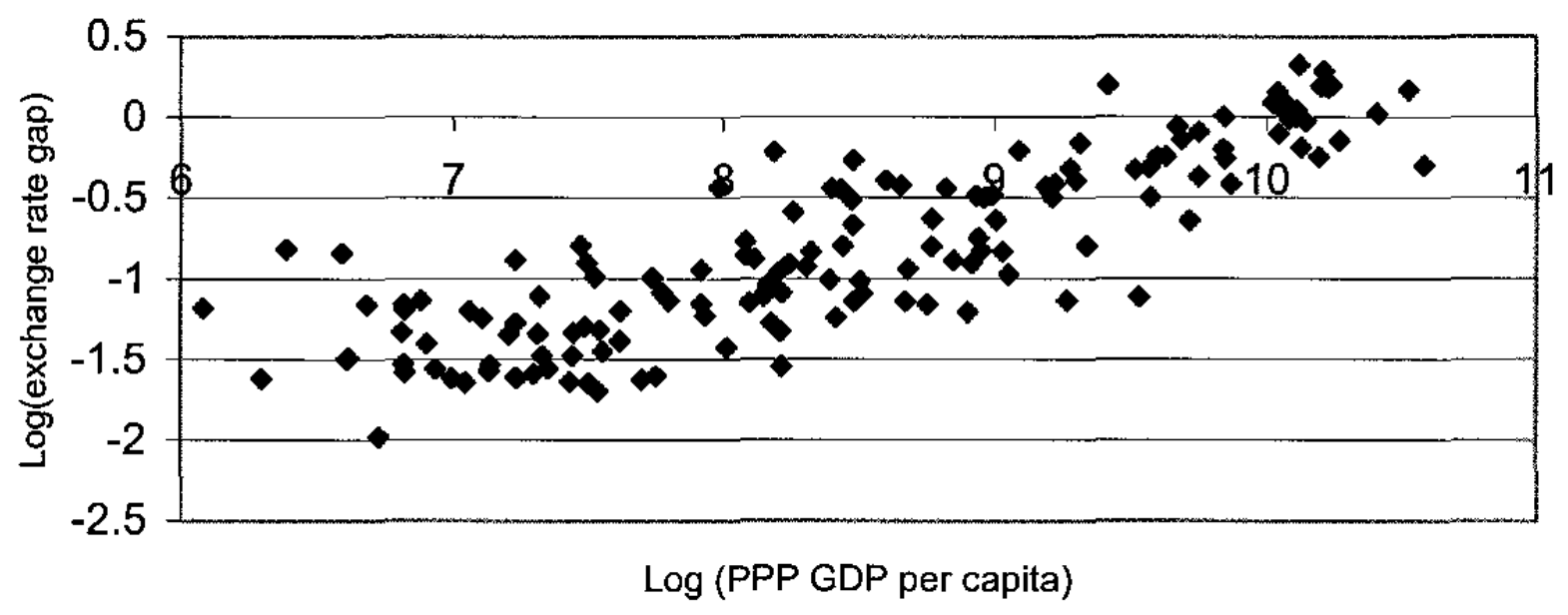


Figure 3. Exchange Rate Gap and Income Level for EU Accession Countries

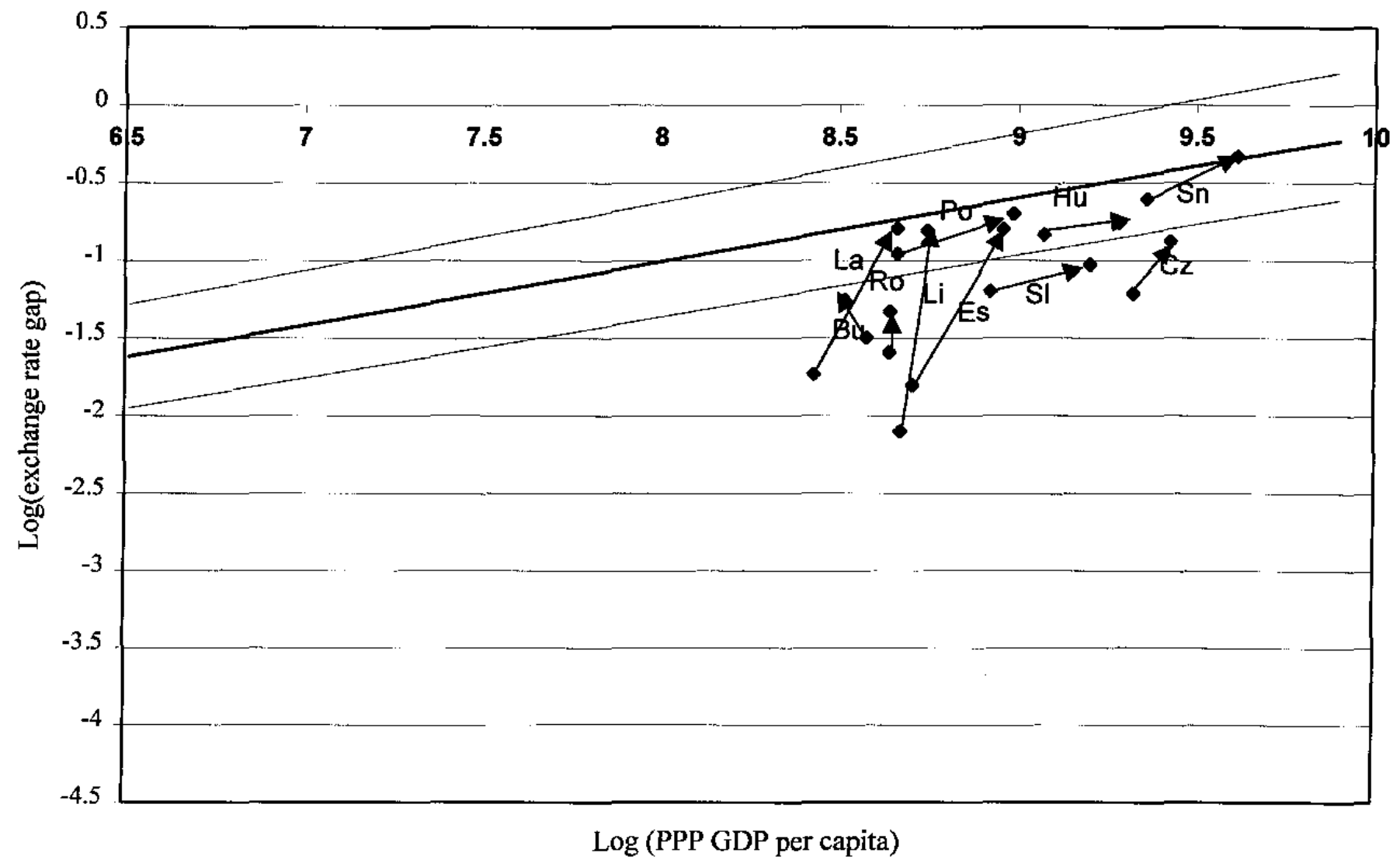

Note: $\mathrm{Hu}=$ Hungary, $\mathrm{Sn}=$ Slovenia, $\mathrm{Sl}=$ Slovakia, $\mathrm{Cz}=$ Czech Republic, $\mathrm{Po}=$ Poland, $\mathrm{Es}=$ Estonia, $\mathrm{Li}=$ Lithuania, $\mathrm{Ro}=$ Romania, $\mathrm{La}=$ Latvia, $\mathrm{Bu}=$ Bulgaria 
Figure 4. Exchange Rate Gap and Income Level for Selected Transition Countries

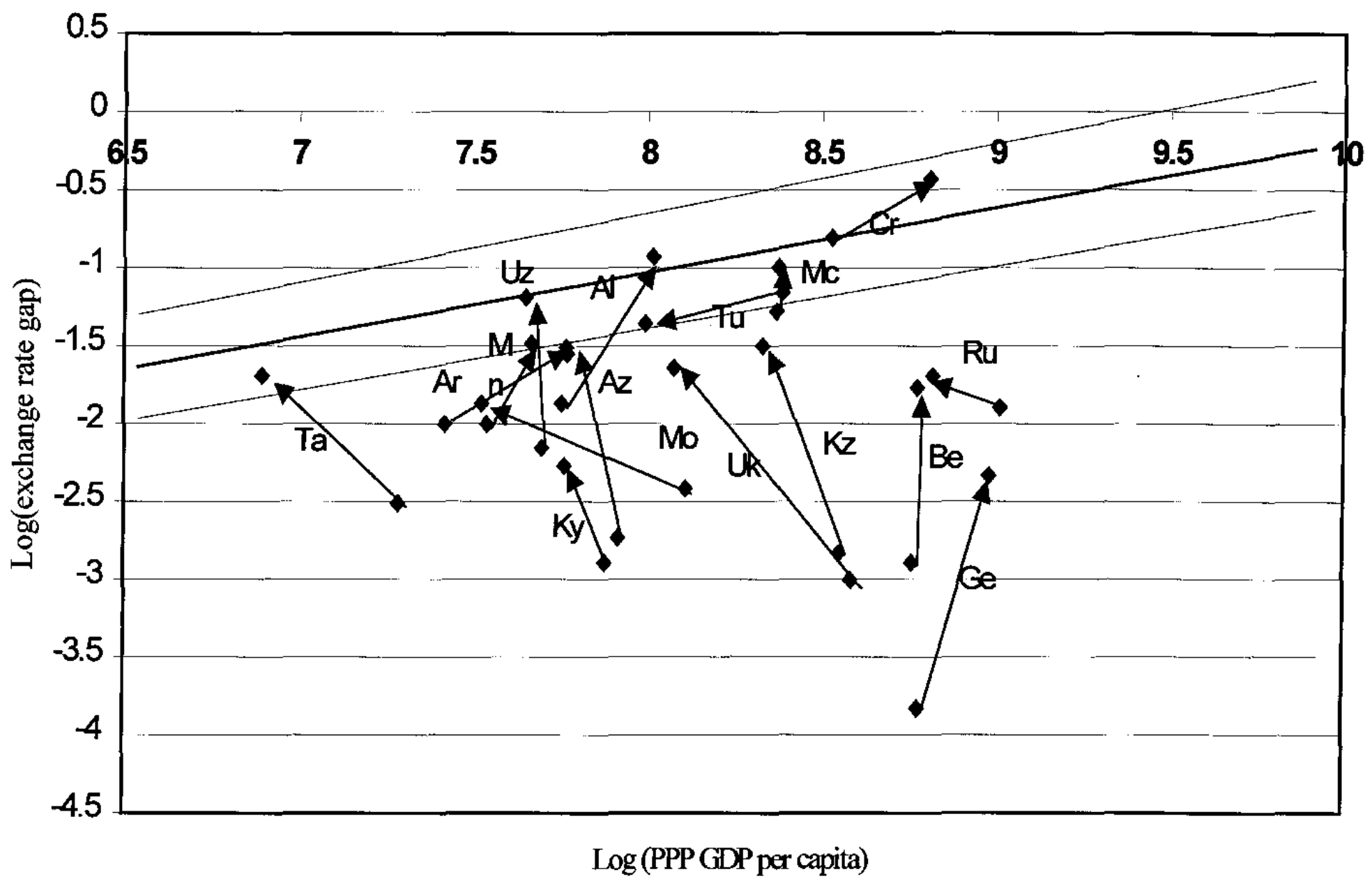

Note: $\mathrm{Ta}=$ Tajikistan, $\mathrm{Uz}=$ Uzbekistan, $\mathrm{Ar}=$ Armenia, $\mathrm{Al}=$ Albania, $\mathrm{Mn}=$ Mongolia, $\mathrm{Mo}=$ Moldova, $\mathrm{Ky}=$ Kyrgyz Republic, $\mathrm{Az}=$ Azerbaijan, $\mathrm{Uk}=$ Ukraine, $\mathrm{Mc}=$ Macedonia, $\mathrm{Tu}=$ Turkmenistan, $\mathrm{Be}=$ Belarus, $\mathrm{Ru}=$ Russia, $\mathrm{Ge}=$ Georgia, $\mathrm{Cr}=$ Croatia, $\mathrm{Kz}=$ Kazakhstan . 


\section{Data Appendix}

\section{Exchange Rate Ratio Data}

The purchasing power parity-based U.S. dollar exchange rates are based on the 1996 round of surveys from the International Comparison Programme (ICP). The ICP is coordinated by a number of international organizations and collects data on prices paid for a large sample of comparable items in more than 100 countries. The World Bank collects detailed ICP benchmark data from regional sources and establishes consistency across the regional data sets. In addition, the World Bank computes regression-based estimates for nonbenchmark countries and extrapolates the data beyond 1996. The 1999 data are published in the 2001 issue of the World Development Indicators.

\section{Central and Eastern European Countries}

Production by sector: Vienna Institute for International Economic Studies Countries in Transition Handbook in Statistics, 1994-1999. Planecon, various years. Employment by sector: Vienna Institute for International Economic Studies Countries in Transition Handbook in Statistics, 1994-1999. Planecon, various years.

Broad money: M3 taken from World Economic Outlook database, International Monetary Fund.

Openness: Exports plus imports divided by GDP. From World Economic Outlook database, International Monetary Fund.

Government balance: Government balance as a percentage of GDP. From World Economic Outlook database, International Monetary Fund.

Terms of trade: From World Economic Outlook database, International Monetary Fund Fuel commodity prices: From World Economic Outlook database, International Monetary Fund.

Non-fuel commodity prices: From World Economic Outlook database, International Monetary Fund.

\section{Other Transition Countries}

Production by sector: Statpro: Official Statistics of the Countries of the Commonwealth of Independent States, 1996-1999.

Employment by sector: Statpro: Official Statistics of the Countries of the Commonwealth of Independent States, 1996-1999.

Broad money: M3 taken from International Financial Statistics database, International Monetary Fund.

Openness: Exports plus imports divided by GDP. From World Economic Outlook database, International Monetary Fund.

Government balance: Government balance as a percentage of GDP. From World Economic Outlook database, International Monetary Fund.

Terms of trade: From World Economic Outlook database, International Monetary Fund. 
Fuel commodity prices: From World Economic Outlook database, International Monetary Fund.

Non-fuel commodity prices: From World Economic Outlook database, International Monetary Fund.

\section{OECD Countries}

Production by sector: National Accounts of OECD Countries, OECD.

Employment by sector: Labor Force Statistics, OECD.

Broad money: M3 taken from World Economic Outlook database, International Monetary

Fund.

Openness: Exports plus imports divided by GDP. From World Economic Outlook database, International Monetary Fund.

Government balance: Government balance as a percentage of GDP. From World Economic Outlook database, International Monetary Fund.

Terms of trade: From World Economic Outlook database, International Monetary Fund. Fuel commodity prices: From World Economic Outlook database, International Monetary Fund.

Non-fuel commodity prices: From World Economic Outlook database, International Monetary Fund. 


\section{REFERENCES}

Alberola, Enrique, Susana Cervero, Humberto Lopez, and Angel Ubide, 1999, "Global Equilibrium Exchange Rates: Euro, Dollar, "Ins," "Outs," and Other Major Currencies in a Panel Cointegration Framework," IMF Working Paper 99/175 (Washington: International Monetary Fund).

Balassa, Bela, 1964, "The Purchasing Power Parity Doctrine: A Reappraisal," Journal of Political Economy, Vol. 72, No. 6, pp. 584-596.

Bayoumi, Tamim, Takatoshi Ito, Peter Isard, and Stephen Symansky, 1996, Exchange Rate Movements and Their Impact on Trade and Investment in the APEC Region, IMF Occasional Paper No. 145 (Washington: International Monetary Fund).

Begg, David, László Halpern, and Charles Wyplosz ,1999, Monetary and Exchange Rate Policies, EMU and Central and Eastern Europe, Forum Report of the Economic Policy Initiative No. 5 (London: CEPR).

Calderón, César, 2000, "Equilibrium Real Exchange Rates in the New Open Economy Macroeconomics," (unpublished manuscript; Rochester: University of Rochester).

Canzoneri, Matthew, Robert Cumby, and Behzad Diba, 1999, "Relative Labor Productivity and the Real Exchange Rate in the Long Run: Evidence for a Panel of OECD Countries," Journal of International Economics, Vol. 47, pp. 245-266.

Chinn, Menzie and Louis Johnston, 1997, "Real Exchange Rate Levels, Productivity and the Real Exchange Rate in the Long Run: Evidence for a Panel of OECD Countries," IMF Working Paper 97/66 (Washington: International Monetary Fund).

Cipriani, Marco, 2000, "The Balassa-Samuelson Effect in Transition Economies," (unpublished manuscript; Washington: International Monetary Fund).

De Broeck, Mark, and Vincent Koen, 2000, "The Great Contractions in Russia, the Baltics, and Other Countries of the Former Soviet Union: A View from the Supply Side," in International Monetary Fund, World Economic Outlook Supporting Studies, (Washington), pp.161-183.

De Gregorio, Jose and Holger Wolf, 1994, "Terms of Trade, Productivity, and the Real Exchange Rate," NBER Working Paper No. 4807 (Cambridge, MA: NBER).

Frenkel, Jacob and Michael Mussa, 1985, "Asset Markets, Exchange Rates, and the Balance of Payments," Chapter 14 in Gene Grossman and Kenneth Rogoff (eds.), Handbook of International Economics, Vol. 2 (Amsterdam: North Holland), pp. 679-747. 
Grafe, Clemens, and Charles Wyplosz, 1999, "A Model of the Real Exchange Rate

Determination in Transition Economies," in Mario Bléjer and Marko Škreb, Balance of

Payments, Exchange Rates, and Competitiveness in Transition Economies (Boston:

Kluwer Academic Publishers), pp. 159-184.

Halpern, László, and Charles Wyplosz, 1997, "Equilibrium Exchange Rates in Transition Economies," IMF Staff Papers, Vol. 44 (December), pp. 430-61.

Jakab, Zoltán, and Mihály András Kovács, 1999, "Determinants of Real-Exchange Rate Fluctuations in Hungary," NBH Working Paper 1999/6.

Krajnyák, Kornélia, and Jeromin Zettelmeyer, 1998, "Competitiveness in Transition Economies: What Scope for Real Appreciation?" IMF Staff Papers, Vol. 45 (June), pp. 309-62.

MacDonald, Roland, 1998, "What Do We Really Know About Real Exchange Rates?" Oesterreichische Nationalbank Working Paper No. 28.

Maliszewska, Maryla, 1997, "Modelling Real Exchange Rate in Transition: The Case of Poland and Romania," CASE Foundation, S\&A No. 131.

Mussa, Michael, 1984, "The Theory of Exchange Rate Determination," in John Bilson and Richard Marston (eds.), Exchange Rate Theory and Practice, NBER Conference Report (Chicago: Chicago University Press), pp. 13-58.

Obstfeld, Maurice, and Kenneth Rogoff, 1996, Foundations of International Macroeconomics (Cambridge, MA: MIT Press).

Panagiotis Liargovas, 1999, "An Assessment of Real Exchange Rate Movements in the Transition Economies of Central and Eastern Europe," Post-Communist Economies, Vol. 11, No.3, pp. 299-318.

Pesaran, Hashem, and Ron Smith, 1995, "Estimating Long-run Relationships from Dynamic Heterogeneous Panels," Journal of Econometrics, Vol. 68, No.1, pp. 79-113.

Pesaran, Hashem, Yongcheol Shin, and Ron Smith, 1999, "Pooled Mean Group Estimation of Dynamic Heterogeneous Panels,"Journal of the American Statistical Association, Vol. 94, No. 446, pp. 621-634.

Philipp, Rother, 2000, "The Impact of Productivity Differentials on Inflation and the Real Exchange Rate: An Estimation of the Balassa-Samuelson Effect in Slovenia," IMF Staff Country Report 00/56 (Washington: International Monetary Fund), pp. 26-38.

Samuelson, Paul, 1964, "Theoretical Notes on Trade Problems," Review of Economics and Statistics, Vol. 46, No.2, pp. 145-154. 
Szapáry, György, 2000, "Maastricht and the Choice of Exchange Rate Regime in Transition Countries During the Run-up to EMU," NBH Working Paper 2000/7. 